\title{
Money and Inflation in Israel: The Transition of an Economy to High Inflation
}

\author{
ZALMAN F. SHIFFER
}

I SRAEL is a small, open economy with a population of about 4 million and a per capita national income in 1981 of about $\$ 5,400{ }^{1}$ For a long period, until the begiming of the $1970 \mathrm{~s}$, it had experienced relatively low inflation and high real economic achievements in terms of employment, economic growth and consumption. During the 1970s; however, Israel's economic performance deteriorated sharply: real GNP growth fell from about 9 percent to 3 percent per year, and the rate of inflation accelerated dramatically to over 100 percent per year (tmemployment, however, remained relatively low for most of the decade). At the same time, the import surplus - the difference between the value of imports and exports - rose to levels that were considered unmaintainable in the long run (see tables 1 and 2$)^{2}$

The dismal experience of the Israeli economy, like similar developments in other countries, was related to the economic adjustment to higher energy prices. Other countries also were subject to lower real growth and higher inflation since 1973. However, the acceleration of inflation was particularly acute in Israel (see table 3). In addition to the oil price shocks, Israel faced

\footnotetext{
The degree of the openness of an economy is measured by the importance of its economic relations with the rest of the world. In 1981 imports and exports were, respectively, equal to 68 percent and 48 percent of GNP in Israel (compared with 9 percent and 8 percent in the United States?.

SSince the establishment of the state. Israel has always inported more than it exported, finarcing the difference by foreign gants and by the actumulation of foreign debt (which reached $\$ 18$ billion at the end of 1981 ). The authorites were concerned about the possibility of future reduction in the avalability of interational finanacing and, to avoit the potential high costs of a rapid adjustment to a lower import suphus, amed at its gradual reduction.

For additional infomation (in English) on the Israeli economy in general and on monetary polieies and developments in particular, see Bank of Israel Anmal Reports and Economic Review. See in parficular Stanley Fischer, "Monetary Policy in Istael" Bank of Isael Economic Retieu No. 53 (May 1982), pp. 5-30. For an earlier period, see Nadav Halevand Ruth Klino Halul, The Economic Development of 1srael (Praeger, 1968). See also Nadav Halevi,

"Economic Policy Discussion and Researeb in Israe," American Economic Review, Supplement (September 1969).
}

changing military and political conditions that resulted in higher levels of defense expenditures and govern ment deficits. The deterioration of the Israeli economic performance in the 1970 s was, therefore, also related to the effect of the external burdens imposed on Israel. Finally, the rapid transition to high inflation also reflected the relative low priority assigned by policymakers to the goal of price stabilization and the specific mix of policy measures used to achieve the different policy goals.

The purpose of this article is to discuss the sources and mechanisms of monetary growth in Israel $I$ in particular the inflationary process during the past decade. Section 1 discusses the relative importance of the changes in money demand and money supply in the Israeli inflationary process. Section 2 surveys the sources of money supply growth, with special emphasis on the financing requirements of the public sector. Section 3 discusses how the exchange rate policy and the debt management policy have created a highly adaptive money supply process, and section 4 deals with the short- and long-run implications of this strueture on the inflationary process. Section 5 analyzes the historical evolution of the inflationary process and, finatly, section 6 offers some conchuding remarks.

\section{MONEY DEMAND, SUPRLY AND TNPLATION}

Inflation can be defined as a sustaned increase in the general price lvel or, equivalently, as a sustained erosion of the value of money (i.e., the amount of goods and services that one unit of local currency - say a dollar or a Shekel) will buy. ${ }^{3}$

The equilibrium value of money, like that of any other commodity, depends on its demand and supply. People generally are not interested in the number of monetary units that they possess - their nominal money holdings; instead they are concemed abont the

\footnotetext{
'In 1980 , lsrael changed its monetary unit from the pound (L) to the snekel (IS) at the ratio of 10 IL per IS.
} 
Table 1

GNP, Prices and Unemployment

\begin{tabular}{|c|c|c|c|c|}
\hline Period & $\begin{array}{l}\text { Nominal } \\
\text { GNP growh }\end{array}$ & $\begin{array}{l}\text { Feal } \\
\text { GNP growth }\end{array}$ & $\begin{array}{l}\text { Change in } \\
\text { Implicil GNP } \\
\text { prifoe deflator }\end{array}$ & Unernployment rate \\
\hline 1960.65 & $18 \%$ & $9.5 \%$ & $8 \%$ & $38 \%$ \\
\hline 1966.69 & 12 & 75 & 4 & 74 \\
\hline 1970 & 17 & 79 & 8 & 38 \\
\hline 1971 & 25 & 170 & 13 & 3.5 \\
\hline 1972 & 28 & 123 & 14 & 2.8 \\
\hline 1973 & 26 & 4.1 & 21 & 2.6 \\
\hline 1974 & 41 & 46 & 35 & $3: 0$ \\
\hline 1975 & 42 & 32. & 37 & 3.1 \\
\hline 1976 & 29 & 1.3 & 27 & 3.6 \\
\hline 1977 & 45 & 13 & 43 & 39 \\
\hline 1978 & 63 & 4.1. & 55 & 36 \\
\hline 1979 & 89 & 30 & 82 & 29 \\
\hline 1980 & 138 & 27 & 128 & 48 \\
\hline 1981 & 137 & 46 & 126 & \\
\hline
\end{tabular}

As a percent of the ovilar labor rorco.

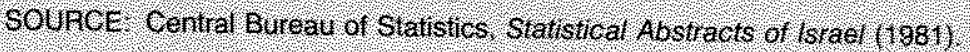

\section{Table 2}

\section{Allocation of Economic Resources}

\begin{tabular}{|c|c|c|c|c|c|c|}
\hline fertod & $\begin{array}{l}\text { Priate } \\
\text { consumption }\end{array}$ & \multicolumn{2}{|c|}{ Poblo consurmption } & lovestrent & suports? & surpust \\
\hline & & (4) & percento & & & \\
\hline$\sqrt{1966.60}$ & $66 \%$ & $26 \%$ & $17 \%$ & $22 \%$ & $19 \%$ & 6645 \\
\hline 1970 & $61 \%$ & 36 & 25 & 29 ? & 27 & 4288 \\
\hline 1971 & 58 & 34 & 23 & 32 & 24 & 4226 \\
\hline 1972 & 57 & 31 & 21 & 30 & 21 & 4,101 \\
\hline 1973 & 59 & 44 & 33 & 34 & 37 & 17704 \\
\hline 1974 & 62 & 42 & 30 & 06 & 30 & 0324 \\
\hline 1975 & 62 & 48 & 35 & 33 & 40 & 4106 \\
\hline 1976 & 65 & 42 & 82 & 28 & 34 & 3200 \\
\hline 1977 & 63 & 37 & 25 & 25 & 25 & 2535 \\
\hline 1978 & 65 & 40 & 27 & 27 & 31 & 3283 \\
\hline 1979 & 64 & 36 & 23 & 29 & 29 & \\
\hline 1880 & 62 & 37 & 25 & 24 & 20 & 3927 \\
\hline 1081 & 68 & 39 & 27 & 22 & 20 & \\
\hline
\end{tabular}

The difference between the value of impots and exports

2 hrintons or $0 \mathrm{~S}$ dollars

Sounce. central Bureat of Staistics, Statistical Abstract of lsraer $(1987)$ 


\begin{tabular}{|c|c|c|c|c|c|}
\hline Country & 196069 & $1970-73$ & 197475 & $1976 \cdot 78$ & 1979880 \\
\hline Istael & $5,2 \%$ & $127 \%$ & $39.5 \%$ & $39.2 \%$ & $103.0 \%$ \\
\hline United States & 23 & 49 & 101. & 66 & 12.4 \\
\hline United Kingdom & $3: 4$ & 8.0 & 200 & 13.5 & 15.7 \\
\hline 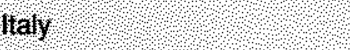 & 3.7 & 6.6 & 18.1 & 15.3 & 179 \\
\hline West Germany & 2.4 & 5.3 & 6.5 & 3.6 & 48 \\
\hline Argentina & 22.2 & 40.3 & 86.6 & 245.7 & 128.3 \\
\hline Chile? & $28.5^{2}$ & 89.5 & 436.1 & 103.1 & 34.3 \\
\hline Brazi: & 44.2 & $17: 9$ & 283 & .415 & 67.1 \\
\hline $\begin{array}{l}\text { Industrial countries } \\
\text { Western Hernisphere }\end{array}$ & 29 & 5.8 & 12.2 & 8.0 & 10.6 \\
\hline (excluding US \& Canada) & 211 & 205 & $36:$ & 48.8 & 51.8 \\
\hline World: & 41 & 6.0 & 144 & 10.8 & 13.5 \\
\hline
\end{tabular}

IBased on rates of change for average yearty price levels

20omputed for 196469 oetiod.

SOURGE. Intenational Monetary Fund, Iniemational Financial Statistics Yearbook 1981 .

quantity of goods and services that their money balances can purchase - the real value of these holdings. In other words, the equilibrium value of money, or the price level, depends on the demand for real money balances and on the nominal money supply.

Over time, the rate of change of the price level (i.e., the rate of inflation) will reflect the difference between the rates of growth of the nominal money supply and of the real money demand. ${ }^{5}$ In analyzing an inflationary process, therefore, it is instructive to consider the forces governing the changes in real money demand and nominal money supply.

Chart la shows the rate of change of the narrowly defined money supply $M_{1}$ (local currency and demand deposits) and the rate of change of the consumer price level; ${ }^{6}$ the difference between these two rates is the

${ }^{4}$ Formally, in equilibrim, $\mathrm{P}=\mathrm{M} /(\mathrm{M} / \mathrm{P}) \mathrm{d}$, where $\mathrm{P}$ is the general price level, $M^{s}$ is the nominal money supply and $(M / P) d$ is the real money demand

${ }^{5}$ At any point in time, the price level may not equate exactly the demand for and supply of noney, however, these deviations are of secondary importance when a longer period is considered. The exact relation anong the equilibrium rates of change of the price level, money supply and noney demand is $\hat{P}=\hat{M}-\hat{\mathrm{M}} \mathrm{d}) / \mathrm{l}+$ Md) where " represents a rate of change.

"Casnal observation suggests a considerable use of foretgn exchange bills and of ehecks drawn upon overdraft facilities for transactions in Israel. It has been suggested, therefore, that a more accurate definition of the "means of payments" should include foreign exchange cash hotdings and lines of credit for overal raft unfortunately, the statistical coverage of these variables is highy ansatisfactory. rate of change of the real quantity of money. An index of the real quantity of money is presented in chart $1 \mathrm{~b}$.

Chart 1 reveals that, since 1973 , the real value of the money stock has decreased dramatically (by about 70 percent between the end of the 1973 and the end of

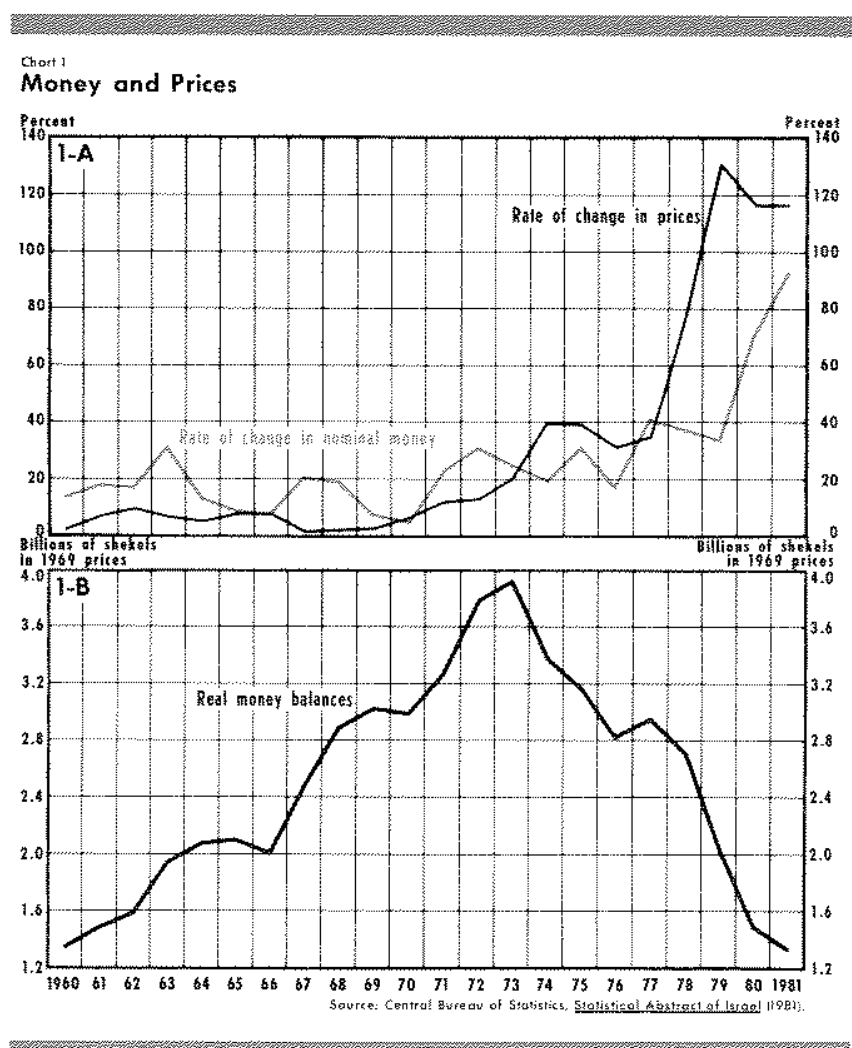


1981). This reduction mainly reflected the reaction of the real demand for money to the increase in the cost of holding money - which bears no interest - as the rate of inflation accelerated and interest rates increased. The increase in money velocity was facilitated by financial innovation which, to a large extent, was also induced by the rise in the cost of holding money. ${ }^{7}$ Some "autonomous" financial innovation was also present, and the demand for money also may have been affected by changes in real wealth.

Even if the reduction in the real quantity of money were fully attributable to shifts in money demand, it could only explain a small part of the accumulated increase in prices. ${ }^{9}$ Since the reduction in the real money balances was, in fact, primarily a product of inflation, the main factor explaining the Israeli inflationary experience is the behavior of the money supply.

\footnotetext{
TThe cost of holding money is the fifference between the nominal return on other assets - physical assets and interest-bearing financial assets - and the zero nominal returiz on money. As the rate of inflation increases, the gap between the return on physical goods and money widens, and the rates of interest on financial assets adjust upward (either as a result of the incorporation of inflationary expectations in nominal rates of interest or the higher retinn gained on indexed assetsi. In recent years, there has also been an increase in real rates of interest in Israel (i.e., after allowing for the effect of higher inflation on the rate of interest).
}

The effect of the cost of holdng money on financial innovation takes time to work out. This may at least partly account for the fact that real money balances continued to decrease for two or three years after each of the wo major episodes of inflationary acceleration in Esrael.

The income velocity of money, defined as the ratio between nominat $G N P$ and $M_{1}$ (or, altematively, between real $G N$ and real money balances increased from 6 in 1973 to 24 in 1981 .

The real demand for money has been investigated by Leomarto Leiderman and Arye Marom in "New Estimates of the Demand for Money in 1sael" (Bank of Isael [B.O.I.] Research Dept. June 1951) and by Rafael Melnick in "Two Issues Conceming the Demand for Money in Inael" (B. O. I. Research Dept, Jantlary 1982). Both studies point to strong effeets of the cost of holding money on its demand. They found some varameter changes in the wost-1977 period, but were unable to reject the hypothesis of the function stability by a Chow Test. (1977 was chosen as a possible tuming point becatse of the miny changes accompanying the foreign exchange reform, induding the antonomous introkluction of a new class of money substitute - see below.

These authors dit not investigate the impossble effect of a wealth shock on the demand for money around 1974 . Such a shock may have resulted from the combination of the effect of the oil price increases and the increase in defense outlays. However, a wealth shock also should have affected the demand for private consumption, and there is no indication of a shift in consumption dentand at the time.

At the end of 1981 , the price level was about 100 times hioher than at the end of 1969 and about 55 tines higher than at the end of 1973 ).

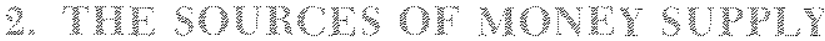 CMAPCOS ISPAEL}

Changes in the nominal quantity of money can be apportioned between those originating from changes in the monetary base and those resulting from changes in the "money multiplier" (the ratio between the quantity of money and the monetary base). ${ }^{10}$ Table 4 shows the extent to which the Israeli money multiplier has fuctuated from year to year. In some years, it has been an important determinant of the change in the money supply; over the long run, however, its changes have had only a secondary effect on the money supply. We shall, therefore, focus the analysis on the factors affecting growth in the monetary base.

Changes in the monetary base are created by the net flow of payments between the economic authorities and the private sector. In Israel, changes in the monetary base equal:

a) The domestic deficit of the government and other parts of the public sector in its nonfinancial activities; ${ }^{11}$

plus b) The net flows of loans from the public sector and the central bank to the private sector. These loans are granted on favorable terms to investors, exporters and to housing mortgages;

minus of The net sale of foreign exchange by the Bank of Israel (B.O.I.) to the private sector ${ }^{12}$

minus d) The net sale of government and B.O.I. debt to the private sector.

To demonstrate the significance of these flows, table 5 presents the evolution of the changes in the monetary base and in the flows affecting these changes as a

\footnotetext{
"In this artele, we use the Israeli "Broad Money Base." This aggregate excludes bank licuidity deficiencies, which are the Israeli conterpart of the U.S. bormwing at the discount window. For the purpose of money supply analysis, this aggregate is sinilar to the U.S. nombormed monetary base.

${ }^{1}$ The direct transactions of the Ismeli government with the rest of the wotd have no effect on the monekary lase and therefore only domestic deficits are induded. The finatial transactions of the authorities with the (domestic) private sector are included in (b), (c) and (d).

"Except for a few years, the B.O.I. has been a net seller of foreign exchange to the private sector and net purchaser of foreign exchange from the govemment. The goverment actuires foreign exchange through foreign borrowing and unilateral transfers from abroad, spends a part of the proceeds on its direct imports and sells another part to the B.O. I. to finance its domestic expenditures As a reszilt the government has not accumulated al large debt to the B.O.I.
} 
Table 4

\section{The Money Multiplier and Its Contribution to Money Growth}

\begin{tabular}{|c|c|c|c|}
\hline Perrod & $\begin{array}{l}\text { Money nultipler } \\
\text { (end ot penod) }\end{array}$ & rate or change in & $\begin{array}{l}\text { Contribution o change } \\
\text { to the money hultiplet } \\
\text { to the chango n money supply }\end{array}$ \\
\hline 196169 & 123 & $0 \%$ & $3 \%$ \\
\hline 1970 & 116 & 49 & 37 \\
\hline 1971 & 104 & 103 & 37 \\
\hline 1972 & 102 & 419 & 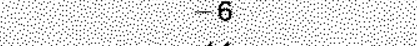 \\
\hline 1970 & 101 & 49 & 14 \\
\hline 1974 & 108 & 09 & 9 \\
\hline 1975 & 1224 & 14.8 & 67 \\
\hline 1076 & $1 \longdiv { 3 }$ & 89 & 33 \\
\hline $197 \%$ & 107 & 053 & 18 \\
\hline 1978 & 120 & 122 & 26 \\
\hline 1979 & 1.28 & 67 & 23 \\
\hline 1980 & 145 & $5^{6}$ & 5 \\
\hline 1981 & 11.14 & 499 & \\
\hline 197081 & 7114 & 413 & \\
\hline
\end{tabular}

The reto of M, to broad nonetary bese.

Change in the noney nutiplier lines monetary base at he begining of the period divided by the change in $M$, during he pertod (and nultipled by 100 )

soynce 196069 . Moshe Sanbar and Sau Bronteld. Monelary Thought, Polcy and Developmen 1948.72, srael Economic Quanerl Review (Aprl 1973) and (Septenber 1973).

1970.81 Bank of Israel Annual Reports.

Table 5

Sources of Change in the Monetary Base (as a percent of GNP)

Donestic deficit
of he pubilc
sector

NOTE Dash indicates data unavailable from accessible sources.

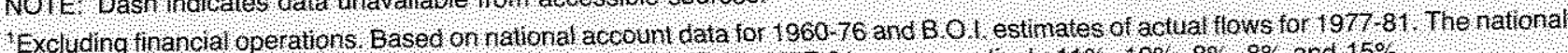
account estimates for the share of domestc deficits in GNP or 1977 81 are respectively $1 \%, 10 \%, 8 \%, 8 \%$ and $5 \%$

SOURCE Sane as table 4 
percentage of $\mathrm{GNP}{ }^{13}$

The share of the domestic deficits of the public sector in GNP, already high by international standards in the $1960 \mathrm{~s}$, rose dramatically to 15 percent in $1973-74$ and thereafter decreased, through remaining relativeby high. These deficits increased primarly because of the higher level of defense expenditures imposed on the Israeli economy since the Yom Kippur War. Domestic defense expenditures rose from an average of 9 percent of GNP in 1968-72 to 16 percent in $1973-$ $81 .{ }^{14}$

While we do not possess adequate quantitative information about the net fows of public loans to the private sector in the 1960 s, we know that their magnitude (relative to GNP) was much lower than in the 1970 s. Most of these loans were granted, until recent years, at low nominal interest rates that were adjusted to the increase in the rate of inflation only partially and belatedy. ${ }^{15}$ This policy brought about a considerable increase in the difference between the flow of new loans, which reflected current prices, and the flow of old loan repayments, which was determined by the historically low prices and rates of interest.

Table 5 reveals that the increase in the share of public deficits and loans in GNP has not been accompanied by an increased reliance on monetary base expansion as a source of government finance (i.e., in the ratio of new monetary base creation to GNP). The average ratio of monetary base change to GNP over the 1973-81 period was equal to its $1960-72$ value ( 2.5 percent). In other words, the net increase in purchases of public debt and foreign exchange by the private sector essentially ofset the increase in the public deficits and credits.

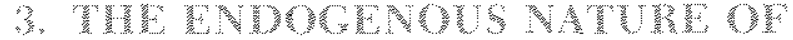 r盖墨}

The previous discussion raises the question: "Why

\footnotetext{
${ }^{13}$ Dete to the way in which monetary base data were publisted, it is diffecut to apportion the sources of change in the nonetary base aceording to our functional classification for the ful period consid erect.

${ }^{1-4}$ Due to increased defanse imports, the increase in the share of total defense outhys in GNP was ever higher see table 2 ). De fense imports, sike other direct government imports, however. have no effect on the monetary base (see above).

${ }^{5}$ Most loans to exporters have been indexed to the foreign exchange rate since 1977 . The indexation of investnent and norlgage lonss, however, was delaved until 1979-8I

The structure of interest rates on public credits had significant adverse effects both on the effeiency of the allocation process and on income and wealth distribution.
}

did the Bank of Israel not increase the sale of foreign exchange and public debt to the private sector and thus bring about a lower rate of money growth and inflation?" The answer to this question is that open market operations in these two assets were governed by considerations other than achieving monetary control.

Sales (and purchases) of foreign exchange by the B.O.I to the private sector are used mainly to stabilize the exchange rate, not to control money and are generally not sterilized). The B.O.I. offers to sell (or buy) whatever quantities of foreign exchange that are necessary to stabilize the exchange rate at a policydetemined level with minor fluctuations being tolerated in recent years). The rate of exchange determination and, consequently, the open market operation in foreign exchange is perceived as an instrument for achieving a gradual reduction in the import surplus, which is considered unmaintainable in the long run. In recent years, the B.O.I. has aimed at stabilizing the real rather than the wominal rate of exchange by equating the rate of exchange depreciation to the difference between the domestic rate of inflation and the rate of infation in Israel's main trading markets. ${ }^{16}$

Most public debt was in the form of government bonds (some of which were held directly by the public and some of which served as coverage for long-term saving schemes, pension funds and the like). These bonds were indexed to the consumer price index and sold to the public in practically unlimited amounts at real rates of interest that were changed infrequently and within a relatively narrow range. Open market operations in public debt were used, to a large extent, to stabilize the real rate of return on government bonds in the secondary market. This policy may have reflected an evaluation that the demand for direct and indirect holding of govemnent bonds is very sensitive to variations in the real rate of return. ${ }^{17}$

\footnotetext{
${ }^{160}$ The real rate of exchange is defined as $\mathrm{EP}^{*} \%$, where $\mathrm{E}$ is the nominal rate of exchange (domestic price of foreign exchange) $P^{*}$ is the level of foreign prices and $\mathrm{P}$ that of domestic prices. Its rate of change is $\hat{\mathbf{E}}-(\hat{\mathbf{P}} \cdot \hat{\mathrm{P}} *$, where "is a notation for rate of change and $(\hat{\mathbf{P}}-\hat{\mathbf{P}} \boldsymbol{*})$ is the difference between the local and foretgn rates of inflation. Note that the implications of a fixed real ate of exchange are different from those of a fixed nominal rate of exchange. While both imply an effect of the balance of payments on the monetary base, a fixed nominal rate of exchange tends to reduce the sensitivity of the local price level to expansionary domestic policies, by shifting the adjustment to the balance-of payments flows.

${ }^{17}$ If this were the case, the govenment could have lowered the average rate of interest that it had to pay on a given amomt of debt by its policy of real interest rate stabilization. This also may have affected the rates of interest charged on nongovermental bornowers.
} 
Some public debt was in the form of foreignexchange-indexed deposits, the volume of which was determined in recent years by the private sector demand. The retum on these deposits depended on the change in exchange rates and on international interest rates and was, therefore, not subject to manipulation for the purposes of monetary control.

Given the elastic supply conditions of foreign exchange and public debt, the private sector was able to determine its net acquisition of these assets and, thus, the net change in the monetary base. As a result, the quantity of money was largely endogenous - that is, determined by the economy rather than by explicit policy decisions. Thus, a recent econometric study has shown that the rate of money growth was significantly affected by past price changes. ${ }^{18}$ This does not mean, of course, that the money supply played no crucial role in the inflationary process. It merely indicates that under the institutional arrangements prevailing in Israel the yrowth of money accommodated and validated prior price changes. The endogeneity of the money stock kas an important bearing on the dynamics of the Israeli inftationary process.

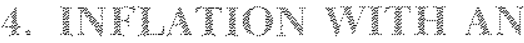

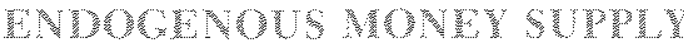

A largely endogenous money supply has important implications for the behavior of short-run price increases, for the determination of the long-run rate of inflation and for the stability of the inflationary process.

The general price level is often subject to short-run movements that cannot be traced to previous changes in money growth or to shifts in the long-run demand for money. The general price level may react to changes in international prices, fiscal actions and many other

\footnotetext{
${ }^{18}$ Elise Brezis, Leonardo Leiderman and Rafael Melnick, "Inflation ancl Monetary Variables: Their Interrekationship in Israel" (B.O.I. Research Dept. September 1981). Using a Granger exogeneity test, these anthors fomd that information about past price changes improves the regression of noney change on its past values both when short lags (several months to a year) and longer lags (up to two vears) are considered. On the ofher hand, they found that information about past money changes improves the regression of price change on its past values only in the long rum.

The long-run results were derived from anmual data over a long period (1954-80). We have repeated these exogeneity tests using quarterly data over the $1965-80$ period. These tests vielded a significant effect of money growth lagged up to three years on prices (and vice versa). When the $1970-80$ period was considered, the effect of lagged money growth on prices was insignificant. Whether this result reflects achange of structure in the 1970 s or is due to the snall number of the tegrees of freedom is maclear.
}

forces that affect the equilibritm in commodity, factor and asset markets (e.g. by creating imbalances between the physical and financial components of the public's portfolios). If the money supply is endogenous, the adjustment of money growth can easily magnify and prolong the effect of these disturbances on the general price level - especially since the public is aware of the accommodating nature of the money supply. This could affect the public's inflationary expectations, resulting in further price increases, even higher growth of the endogenous money supply and downward adjustment of the real demand for money.

This mechanism, which has been at work in Israel for at least part of the period surveyed, explains why accelerations in the rate of price increases have tended to precede accelerations in money growth. Two factors especially have contributed to this mechanism in Israel: (a) The extensive system of indexation transfers price increases from one sector to another quickly and inflates the nominal values of indexed financial assets; (b) The experience with high and rising inflation has increased the speed with which prices adjust and shortened the lag between present price experience and changes in inflationary expectations. ${ }^{19}$

The endogeneity of the money supply also affects the determination of the long-run rate of inflation. With an exogenous money supply, the rate of inflation will converge in the long run to the difference between the given rate of nominal money growth and the rate of growth of real money demand, which depends principally on long-run real economic growth and the elasticity of the demand for money with respect to real GNP. When, however, the money supply is endogenous, as is the case in Israel, there is no predetermined rate of money growth to which the rate of inflation adjusts itself. In this case, both the long-run rates of money growth and inflation are determined simultaneously as a part of a larger and more complex full-equilibrium solution. ${ }^{20}$

A long-run equilibrium interpretation of the acceleration of inflation in Israel has been suggested by

\footnotetext{
${ }^{19}$ The sensitivity of inftationary expectation formation to the level of inflation was investigated in Daniel Gottlieb and Sylvia Piterman, "Inflationary Expectations in Ismel 1965-80" (B.O.I., Research Dept., 1981)

For more evidence on the adjustment of the Israeli economy to inflation, see Zalman F. Shiffer, "Adjusting to High Inllation the Case of Isracl," forthoming in this Review.

zothis solution will include the determination of long-run equilibrium values of the different components of table 6 .
} 
Melnick and Sokoler. ${ }^{21}$ The essence of their argument is that the long-run equilibrium rate of inflation increased in the 1970 s, because (a) the ratio of the revenue from money creation to GNP (the monetary base change/GNP ratio) has been kept unchanged, and (b) in view of the reduction in the rate of real GNP growth, the maintenance of a given monetary base change/GNP ratio required a higher rate of inflation. ${ }^{22}$

The unchanged average level of the share of revenue from money creation in GNP does not, by itself, prove that the inflationary experience of the last decade reflects a transition between long-run equilibrium rates of inflation. Alternatively, this experience could be viewed as the result of a sequence of disturbances, that, given the dynamics of an endogenous money supply, have not necessarily brought the economy to a new long-run equilibrium. ${ }^{23}$ Under this view, the im-

\footnotetext{
${ }^{21}$ Rafael Meluick and Meir Sokoler, "The Covernment's Revenues from Money Creation and the In flationary Effects of a Decline in the Rate of Growth of National Income" B. O.I. heseardh Dept. 1981 ).

${ }^{22}$ Monetary expansion affects the public sector finances not only through the direct revenue that it generates, but also through the effects of the restling inflation on taxation, government spend ing the sale of indexed poblic debt and the erosion of the real value of the unindexed loans given by the public sector to the private sector According to B.O.I. Report 1980 (p. 240), the loss due to loan valae erosion is higher than the direct revente from monetary expansion.
}

Given these relationships, there is no renson to assume that the at thorities maintained a policy aimed at stabilizing the ratio be tween the direct revenue from monetary expansion (the monelary base change) and GNP. Note, however, that the Melnick Sololer argument does not depend on the existence of such a policy, but on the clain that there is a causal effect from the direct revenue from money creation to the rate of inflation. Their argument would also bold if, for example this revenue was endogenously determined by the levels of public deficits and loans and by the foreagn exchange and debt policies. The altemative view discussed below is that the nain causal effect is from the rate of inflation to the revenue from money creation, and not vice versa.

Assuming, for simplicity, that the monetary multiplier is 1 , the ratio of the direct public revenue from money expansion to GNP is: $\triangle \mathrm{M} / \mathrm{PY}=\hat{\mathrm{M}}(\mathrm{M} / \mathrm{PY})$, where $\triangle$ represents absolute change, proportional change and $\mathrm{M}, \mathrm{P}$ and $\mathrm{Y}$ are respectively the nominal quantity of money, the general price level and real CNP. En the long-rum equilibrim, $\hat{\mathrm{M}}=\hat{\mathrm{M} / \mathrm{PY}})+\hat{\mathrm{P}}+\hat{\mathrm{Y}}=\hat{\mathrm{P}}+\hat{\mathrm{Y}}(\mathbf{1}+\eta \hat{\mathrm{P}}$ where $\eta$ is the elasticity at the destred none-GNP natio to real GNP. The long-ran equilibrium revenue from money creation is $(\mathrm{M} / \mathrm{PY})[\hat{\mathrm{P}}+\mathrm{Y}(\mathrm{I}+\eta)]$, where $(\mathrm{M} / \mathrm{PY})$ depends on the expected rate of inflation, which in the long-run equilibrim is equal to the actual rate $\hat{\mathrm{p}}$. This expression is a positive function of $\hat{\mathrm{Y}}$ since $(1+\eta)>0$. When the rate of inflation is increased. $(\mathrm{M} / \mathrm{PY})$ decreases but the "inflationary tax" (W/PY) $\hat{P}$ increases, provided that the elasticity of the demand for money with respect to infla tion is lower than mity in absolute terns; this is the case in frat as well as in most other countries

${ }^{23}$ The problem of the convergence of an ecomomy with an endoge. nous money supply to a long-run stable inflationay efuilibrium is discussed in D. Chappell and D. A. Feel, "On the Dynamic pact of money creation on the public revenue would be interpreted as a result of the acceleration of inflation, instead of its cause.

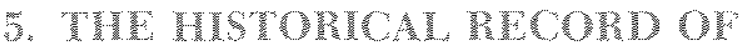

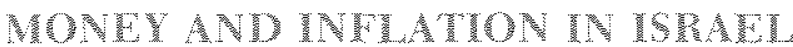

Table 6 contains data relating the dynamic evolution of prices to money growth and other variables over the last decade. This table presents annualized rates of change of the price level, money $\left(\mathbf{M}_{1}\right)$, two larger monetary aggregates $\left(\mathbf{M}_{4}\right.$ and $\left.\mathbf{M}_{5}\right)$, short-term bank credit and the local price of imports. $\mathrm{M}_{4}$ is the sum of $\mathrm{M}_{1}$ and a group of relatively liquid money substitutes - time deposits, CDs, some types of foreignexchange-indexed deposits and tradable, CPI-indexed government bonds. ${ }^{24} \mathrm{M}_{\overline{3}}$, the largest monetary aggre. gate on which data are avaikable for the whole period, is the sum of $\mathrm{M}_{4}$ and some less-liquid savings accounts and foreign-exchange-indexed deposits. Similarly, short-term bank credit represents the largest credit aggregate on which data are available on a long-run basis. The domestic price of imports depends on the rate of exchange and on international prices. ${ }^{25}$

The last four measures are included, because they help illuminate the nature of the relationship between money and prices. These variables reflect, at least partially, the results of policy measures and external shocks and have affected real demands and costs. In particular, statistical tests indicate the existence of

Stability of Monetary Models when the Money Supply is Endogenous," Manchestert School (December 1979), pp. 349-58. The authors assume that the government maintains a given real level of revenue from money creation.

In recent years, it has been argued that the Istael econony might have moved into a stage of "bubble inflation" in which the rate of inflation is indeterminate and can explode as a result of any disturbance or change in expectations. This extreme view is not supported by the evidence: as discussed below, the two principal stages of inflationary acceleration in Israel have been triggered by nontrivial sequences of events and culminated in periods of relative inflationary stability.

${ }^{2}$ The liculdity of these assets is enhanced by the above discussed policies of foreign exchange and real bond interest rate stabilization. While none of these assets serves as a direct means of payment, each is largely held as temporary abole of purchasing power due to its relatively low real risk. Due to the low level of transaction cost relative to the rate of return, these assets are largely purchased for periods of a few weeks. At the end of the 1970s, the velocity of the liquid foreign exchange deposits was close to the velocity of checking acounts at the beginning of the decade.

${ }^{25}$ Due to data limitations, the rate of change of this varable is based on end-of-period quarters (and not months). This implies that a large import price increase which ocurs at the end of a quarter (like the 1974 devaluation) wil also affect the next quarter data. 


\begin{tabular}{|c|c|c|c|c|c|c|}
\hline \multicolumn{7}{|c|}{ Rates of Ohange of Prices, Monetary Aggregates and Credit } \\
\hline Pelloo & $\begin{array}{l}\text { Consuner } \\
\text { price } \\
\text { neser }\end{array}$ & n & $\mathrm{N}_{4}$ & $\mathrm{~N}_{5}$ & $\begin{array}{l}\text { shorternt } \\
\text { tonkeredt }\end{array}$ & $\begin{array}{l}\text { gropts } \\
\text { proes }\end{array}$ \\
\hline 1071 & $13 \%$ & $28 \%$ & $35 \%$ & $36 \%$ & $1 \%$ & $26 \%$ \\
\hline 1972 & $12:$ & 20 & 28 & 25 & 42 & 9 \\
\hline 1973 & 26 & 32 & 50 & 47 & 32 & 31 \\
\hline 1974 & 56 & 18 & 70 & 60 & 71 & 51 \\
\hline 1975 & 23 & 22 & 17 & 26 & 32 & 32 \\
\hline 1976 & 38 & 27 & 19 & 33 & 39 & 36 \\
\hline 1977 & 43 & 38 & 45 & 67 & 85 & 62 \\
\hline 1978 & 46 & 45 & 58 & 61 & 55 & 52 \\
\hline 1979 & 111 & 30 & 83 & 100 & 101 & 102 \\
\hline 1980 & 130 & 90 & 48 & 141 & 10 & 133 \\
\hline & 101 & 78 & 91 & 900 & 87 & 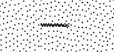 \\
\hline 670970 & 15 & 26 & 34 & 34 & 23 & 19 \\
\hline $9 / 73,1274$ & 53 & 24 & 46 & 56 & 64 & 48 \\
\hline 12749777 & 30 & 29 & 18 & 30 & 37 & 32 \\
\hline 971,278 & 56. & 41 & 78 & 90 & 86 & 71 \\
\hline $12 / 78,1281$ & 96 & 59 & 92 & 98 & 67 & ? \\
\hline \multicolumn{7}{|c|}{ 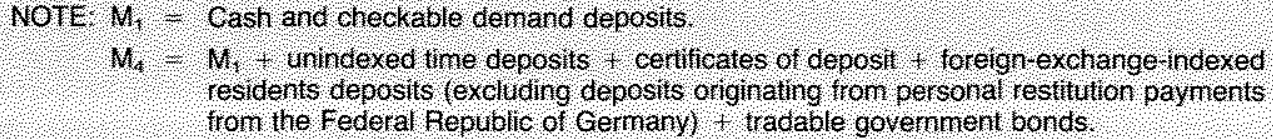 } \\
\hline \multicolumn{7}{|c|}{ 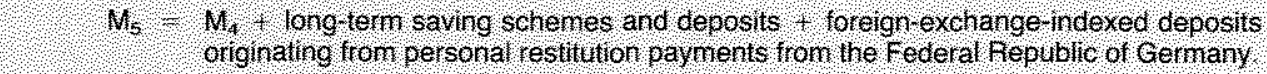 } \\
\hline \multicolumn{7}{|c|}{ 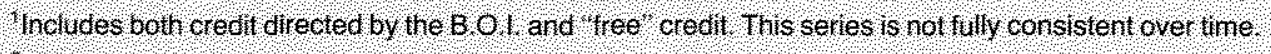 } \\
\hline \multicolumn{7}{|c|}{ 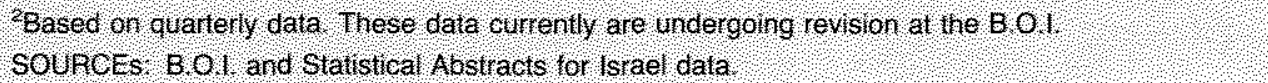 } \\
\hline
\end{tabular}

short-run effects from both $\mathrm{M}_{4}$ and short-run bank credit to prices. ${ }^{26}$ The interpretation of the relationship between these variables and prices, however, must be done carefully, since they are themselves largely endogenous. In particular, the broader monetary aggregates and credits include sizable indexed components, and the rate of exchange also is strongly affected by prices (especially since 1979).

\footnotetext{
${ }^{26}$ See Brezis, Leiderman, Melnek, "Inflation and Monetary Variables." They found a strong short-run effect from credits to prices, weaker effects of $\mathrm{M}_{4}$ on prices and strong effects of prices on both $\mathrm{M}_{4}$ and credil. Credit and the large monetary aggregates have (not surprisingly) more stable velocities than $\mathrm{M}_{1}$.

In recent years, the $B$. O. I. has ased $M$ and short-run bank credit as principal monetary indicators and policy targets. The short-run effect of bank credit on prices may be ane to ther effects on the short-run business liquidity. In Israel businesses lave limited access to altemative sources of finance in the short runand react to credit squeezes by reducing inventories - both through changes in production and througl changes in pricing decisions.
}

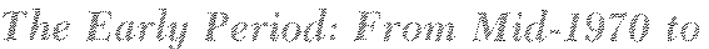 sempomber 197 is}

The transition of the Israeli economy from low to high inflation began in mid-1970; until then, Israel had experienced 16 years of low inflation at abont 5 percent per year. ${ }^{27}$ The rate of price increase hit the 10 percent range in 1970 , rose marginally in $1971-72$ and in the first nine months of 1973 (before the outbreak of the Yom Kippur War) accelerated to an annual rate of 21 percent.

The first round of the higher price increases in 1970 was due to increased indirect taxation. not to an earlier

\footnotetext{
2The country had experenced higher inflation during World Wat II and its first years of independence.
} 
increase in the growth of the money supply $\mathrm{M}_{1}{ }^{28}$ However, money growth took off in the second half of 1970 , reaching an average annual rate of growth of 26 percent between June 1970 and September 1973 (compared with a 15 percent average annual increase in prices - see table 6). This monetary accumulation was part of a general build-up of financial assets. Both $\mathrm{M}_{4}$ and $\mathrm{M}_{5}$ grew at 34 percent per year over the same period as a result of high net sales of foreign exchange by the public to the Bank of Israel. ${ }^{29}$

It would, however, be inacourate to attribute the acceleration of infation in that period solely to forces operating on the supply of money. Between Jume 1970 and September 1973, the domestic price of imports rose at an annual rate of 19 percent. following the imposition of import dufies in 1970 , a 20 percent devaluation in 1971 and international price increases in 1972-73. Had the quantity of money continued to grow at a low rate, these import price increases woll have had a much smaller effect on the general price level (probably joined with lower real activity). However, the fact that money growth began to accelerate only after the first round of price increases (in spite of an earlier increase in the latger monetary aggregates) in dicates that it was, at least in part, adjusting to the short-ran effects of higher import prices. ${ }^{30}$

Finally, one should note that in this period, the increase in the local price of imports was to a certain extent exogenous to the inflationary process, since it was caused by higher foreign commodity prices. $\mathrm{O} n$ the other hand, lower money growth may have prem vented the 1971 devaluation or reduced its size.

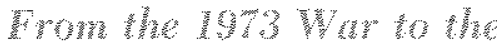

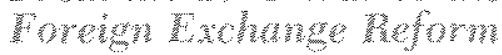

The October 1973 war and the ensuing political and economic international events had strong and lasting effects on the Israeli economy. The real rate of growth

\footnotetext{
${ }^{2}$ The quantity of money rose at an anmul rate of 13 percent be tween the end of 1966 and mid-1970 compared with an average 9 percent real $\mathrm{CNP}$ increase and increased even more slowly in the last 18 months of that period.

${ }^{2}$ The increased sales were due to the combination of an improvement in the private current account and a capifal inflow indeced by relatively high domestio rates of interest and a booming economy.

${ }^{36}$ That the quantity of money was adjusting to demand and not just to supply conditions is evident from the fact that its growth was consideribly lower than that of the lange monetary aggregates both in 1973 and afterward, as higher inflation affected the real demand for money.
}

fell, higher defense and oil import bills widened the current acount deficit and the rise in domestic defense expenditures increased governmental deficits.

Following the outbreak of the war, the B. O.I. conducted a permissive policy, in particular encouraging rapid credit growth. As time passed, however, economic policy began to rellect the growing concern over the balance-of payment situation. Monetary policy became more restrictive, indirect taxation was increased and, in November 1974 , the rate of exchange was devaluated by 43 percent.

The effect of the international oil price increase, the changes in taxation and the devaluation led to sharp price increases which were largely accommodated. The larger monetary aggregates grew rapidly throughout 1974 (although more slowly than before in real terms). The growth of $\mathrm{M}_{1}$, on the other hand, was considerably lower than that of the price level, thus squeezing the real value of the money balances. This development reflected mainly a downward adjustment of real money demand to the higher ate of inflation (see section 1).

The transition to restrictive policies had visible effects in the 1975-77 period. Domestic and foreign deficits shrank, economic activity was low, and all the monetary aggregates grew more slowly than the price level. The rate of inflation came down from its 1974 peak; it remained, however, considerably higher than in the pre-war period.

In June 1975, the government adopted a policy of small and frequent devaluations of aboat 2 percent per month (a "crawling peg system") "3! This policy was motivated by the continuing concem about the balance of payment and a desire to avoid the strong destabilizing effects of large, infrequent devaluations. ${ }^{32}$ As a result of this policy and the absence of external supply shocks, the fluctuations in the rate of in lation were reduced considerably.

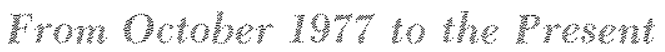

In October 1977, the government embarked on a foreign exchange reform intended to contribute to

\footnotetext{
Whe transition to the crawling peg system at that time might have been interpreted as a signal that the govermment was more committed to adjusting to inflation than to undertaking strong antiinflationary policies.

The expectations for the 1974 devaluation had produced large private capital lows, and the devaluation itself brought about a sharp increase in the general price level.
} 
greater economic efficiency. This reform included:

1) further steps in the liberalization of foreign transactions, in particular of international capital inflows and direct holding of foreignexchange bills;

2) the creation of a universaly accessible class of foreign-exchange-indexed deposits; 33

3) the abolition of direct export subsidies and the reduction and unification of import duties;

4) a transition from the crawhing peg system to a market-determined, flexible exchange rate.

As the reform was enacted, the exchange rate depreciated by 47 percent and the general price level partial. ly adjusted upwards, ${ }^{34}$ As a result of the automatic indexation, the value of fmaneial portfolios also increased.

Between the reform and the end of 1978 , the larger monetary aggregates rose at exceptionally high rates, even when the effect of indexation is taken into account. Thus, $\mathbf{M}_{4}$ and $\mathbf{M}_{5}$ grew respectively at 78 percent and 90 percent annual rates between September 1977 and December 1978 compared with a 56 percent annual increase in the CPI. This increase was fed, to a large extent, by sizable public loans to exporters and arge capital inflows, which were made possible by the reform and induced by the difference between the foreign and domestic interest rate. ${ }^{35}$ This upsurge in public loans and capital inflows reduced the level of real interest rates. The new foreign-exchangeindexed deposits, which offered an attractive mix of liquidity and rate of return, increased rapidly; on the other hand, the growth of $\mathrm{M}_{1}$ was slower than that of the price level.

The increase of the large monetary aggregates and the lowering of real interest rates played a major role in

\footnotetext{
${ }^{33}$ Before the reform, foreign exchange deposit holding was limited to agents engaged in foreign trade, banking institutíns, reeipients of foreign incomes and non-residents. Strictly speaking, the introduction of the new deposits was not part of a foreign exchange reform, since they are fomestic deposits indexed to the foreign exchange, not dams on foreign excharge. These deposits are not checkable

${ }^{34}$ The high depreciation refected in part the adjustment of the formal tate of exchange to the reduction of export subsidies and import auties. The price level rose by 18 percent in the last quarter of the year, compared with an average of 6.5 percent in the three former quarters. Most of the price increase in the last quarter occurred immediately after the depreciation.

3 The domestic cost of foreng borrowing is $i^{*}+\hat{\mathbf{E}}$, where $i^{*}$ is the foreigr rate of interest and $\hat{\mathbf{E}}^{e}$ the expected rate of exchange depreciation. Capital infows at the end of 1978 also were affected by the anticipation of the inusition of constraints on their movements (see below).
}

the increase of real domestic demand and economic activity in 1978 and early $1979 .{ }^{36}$ As the stock of financial assets rose relative to both physical assets and income, the private sector increased its demand for physical assets and other goods and services (especially as investment and purchases of durable goods had been low in previous years). The housing market, a traditional leading sector, experienced a boom, GNP increased rapidly and wages also rose with the demand for labor. Unconstrained by the largely adaptive money supply process, these developments cuminated in a dramatic acceleration of the rate of price increase to about 80 percent in anmal tems at the end of 1978 and the beginning of $1979 .^{37}$

The authorities were alarmed both by this sudden acceleration of price increases and by the fact that, since the reform, the rate of exchange rose considerably more slowly than the general price level. At the begiming of 1979 , the B.O.I. imposed restrictions on capital inflows and domestic bank credit growth and began to stabilize the real rate of exchange through intervention in the foreign exchange market. ${ }^{38}$ The restrictive effect of these measures, which were continued throughout the next years, was reinforced in 1979 by a more restrictive fiscal policy and increased purchases of foreign exchange by the private sector from the B.O.1. ${ }^{39}$

\footnotetext{
${ }^{36}$ High public demand and expectations related to the beyinning of the peacemaking process with Egypt also contributed to the heating up of the economy.

${ }^{37}$ This was twice the ammul rate prevaling during the farst three quarters of 1978
}

Sone observers have argued that the end of 1978 price acceleram tion reflected a delayed reaction to the end of 1977 massive depreciation and relative increase in the price of tradable goods. Such a delayed reaction would have been unusual compared with earlier (and later) adjustments to cost shocks. In addition, the correction of an "excessive" increase in the relative price of tradables would have implied logically only a future lower rate of increase in the rate of exchange relative to the rate of inflation, not recessarily an acceleration of inflation.

${ }^{38}$ Statting in 1979 , the B. O.I. generally imposed periodic ceilings on bank credit growth. These ceilings were partially accommodated to deviations of the rate of price increase from its projected path to reduce the effects of strong real credit crumch on private economic activity. The B.O.I. also imposed a levy on foreign exchange credits (exempting exporters and other favored bonrowers).

The am of the intervention in the foreign exchange market was to equate the average monthly rate of deprectation to the difference between the local and foreign rates of price increase (thus controlling the average real rate of exchange along a "purchasing power parity" path). The B.O.I. did not intervene to prevent "tolerable" daily fluctuations of the rate.

${ }^{30}$ The private sector's current account deficit increased as a result of the rise in oil prices and the high demand for imported durboles at the beginning of the year. The demand for the highly taxed durables also affected the govemment deficit. 
Due to the effect of indexation and higher inflation, the large monetary aggregates increased more rapidly in 1979 than in 1978 , but they were squeezed in real terms. $M_{1}$ increased at an even slower rate than in the previous year and its real value decreased by 38 percent. This reduction may have been affected by the supply forces that reduced the real values of financial portfolios in general, but principally it reflected a reaction of the demand for (non-interest-bearing) money to higher inflationary expectations.

Real rates of interest on private credits increased dramatically and real demand and economic activity slowed down in the second half of 1979 and in 1980.40 Still, the rate of the price increase rose to a new annual peak of 150 pereent in the second half of 1979 , reflecting the short-run effects of energy prices and the reduction of price subsidies.

The rate of inflation remained stubbornly high in 1980 ( 133 percent), apparently as the higher rates of recent price increases were incorporated into inflationary expectations and the still remaining nominal contracts. The growth of the large monetary aggregates outpaced that of price increase and $M_{1}$ grew at 90 percent - still falling in real terms. ${ }^{41}$

The economy resumed a higher real rate of growth in 1981, and, at the same time, the rate of inflation went down. This decrease was led by the short-run effect of a reduction in indirect taxation, which brought the rate of price increase to 94 percent in ammual terms in the first two quarters of the year. Later on, the rate of price increase rose again.

As a result of the reduction in indirect taxation and the adjustment of income tax brackets, there was a sharp increase in the share of the domestic public sector deficit in GNP in 1981. This effect, however, was offset to a large extent by a reduction in the net flow of B.O.I. loans to exporters. The real value of the $\mathrm{M}_{1}$ balances continued to fall, but the growth of $\mathrm{M}_{5}$ kept up with the rate of inflation. ${ }^{42}$ In addition, there

\footnotetext{
"Reat demand and certain financial demands also were affected by the anticipation of additional stricter govermment measures.

${ }^{41}$ The increase in the large aggregates was due, in part, to the effects of lower economic activity and real clemands on taxation and the current account, a reversit of the 1979 developments. In addition, the real maket value of govermment bonds, which had falken in 1979 , went up again.

${ }^{42} \mathrm{M}_{4}$ was reduced somewhat in real terms. This was due to the successful marketing of new saving schemes with shorter redempbon periods (saving schernes are included in $\mathrm{M}_{5}$ but not in $\mathrm{M}_{4}$ ).

It is interesting to note that, while real $\mathrm{M}_{1}$ continned to decrease in 1981 in spite of the reduction in the rate of intation, the
}

was a sharp increase in the real growth of other financial assets. ${ }^{43}$

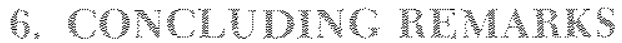

The Israeli experience demonstrates the inflationary hazards of economic policies that subordinate monetary management to the achievement of other goals.

The inadequate monetary control was technically cansed by the expropriation of open market operations in public debt and foreign exchange from the arsenal of monetary instruments. More basically, it reflected the low priority of price stability when compared with other policy goals. This preference was due, to a large extent, to the ability of different economic groups to reduce some of the costs of inflation by indexation and other adjustment mechanisms.

Under the favorable conditions prevailing in the 1950 s and 1960 s, the Bank of Israel was able to maintain a reasonable monetary growth despite the constraints on its policy tools. This situation changed in the 1970s. In that decade, the Israeli economy was taxed heavily by changes in its defense requirements and the international economic environment. The control over monetary growth was lost, and the economy veered rapidly toward high inflation.

Israel has gone a long way along the path of adjustment to inflation, but has been unable to neutralize fully its long-run dismptive effects. The experience with the implementation of partial anti-inflationary measures in 1979-81 reveals also that indexation and other contrivances have not eliminated the short-run costs of disinflation.

The return to reasonable price stability requires effective control over monetary growth. ${ }^{4}$ To achieve

demand for unindexed money substitutes (mainly $C D$ s) increased rapidly. As a result, the value of $\mathrm{M}_{1}$ plus the unindexed money substitutes (known as $\mathrm{M}_{2}$ ) increased in real terms - for the first time since 1972

${ }^{43}$ In recent years, fnancial concems have largely intervened in the stock exchange market to minimize reductions in the real market value of their stocks. This behavior has led to the argument that financial shares may be close in liquidity to government bonds. If the market value of these shares is added to $\mathrm{M}_{4}$ and $\mathrm{M}_{5}$, the rate of growth of these "augnented" aggregates would be much higher than the price level in 1981. Pension funds and other forms of long-term savings that are not included in $\mathrm{M}_{3}$ have also grown rapidly in recent years.

4 The choice of the specific taryet aggregate should depend on the nature of the relationship between different alternative aggregates and prices ind on the controllability of different aggregates While the first of these issues has been only partially investigated in Israel, it seems that aggregates that are tied to an unindered monetary base (ike $M_{1}$ ) could be more easily controlled than others (like $\mathrm{M}_{4}$ ) 
this, the management of at least one of the major sources of monetary base change must be subordinated to monetary considerations. Given the committment to real exchange rate stabilization in Israel, it seems that the best way to achieve monetary control in Israel is through the use of public debt management as an instrument of monetary control - a solution adopted in many other countries. It should be recognized, however, that if, at the same time, the real value of public deficits and loans is not reduced, the Bank of Israel will be confronted continuously with pressures to adopt accommodating policies. ${ }^{4.5}$

"These pressures may arise in reaction to two possible effects of high levels of pullic deficits and loans: al these deficits and credits may create shortm upward pressures on the rate of inflation -um eitier through the dired effect of the demand that they finance, or through the effect of rapid public debt accumulation by the private sector; bi to the extent that large net sales of public debt are used to finance public deficits, they exert upward pressire on real interest rates and crowd out private borrowers.
The optimal pace of disinflation in Israel may be more rapid than in lower-inflation economies that have not developed similar price adjustment mechanisms. Whatever the pace chosen, it is important that disinflation be carried out in a consistent way, since stop-go policies reduce the credibility of the policymakers and raise the pains of disinflation; in a democratic society like Israel, such policies may even altogether frustrate the disinflationary effort.

While the reduction of public deficts and loans also can contribute to a more efficient resource allocation, the use of direct costreducing measures in the process of inflationary deceleration is more problematic cost-reducing measures include reductions in indirect taxation, the lowering of the real ratte of exchange and interention in private proe and wage detemination). Such measures may increase the public sector fleficit, induce destabilizing spectation and interfere with the efficiency of resource allocation. They should therefore, be considered only as a short-rut expediency and as a part of a comprehensive policy based on monetary control and lower public fleficits and loans. 